\title{
MENGONSTRUKSI RANCANGAN SOAL DOMAIN KOMPETENSI LITERASI SAINTIFIK SISWA SMP KELAS VIII PADA TOPIK GERAK LURUS
}

\author{
Adib Rifqi Setiawan*, Setiya Utari, Muhamad Gina Nugraha \\ Departemen Pendidikan Fisika Fakultas Pendidikan Matematika dan IImu Pengetahuan Alam Universitas \\ Pendidikan Indonesia \\ *email: adibrifqisetiawan@gmail.com \\ Ponsel: +62-858-6616-3117
}

\begin{abstract}
ABSTRAK
Seiring perkembangan zaman, literasi saintifik dipilih sebagai tujuan utama pendidikan sains. Literasi saintifik dianggap bisa digunakan untuk mempersiapkan generasi saat ini untuk menghadapi saat nanti. Literasi saintifik adalah pemahaman terhadap konsep dan proses sains serta bisa menggunakan pemahaman tersebut dalam keseharian. Sebagai tujuan utama dalam pendidikan sains, literasi saintifik dalam keseharian masyarakat menjadi gambaran keberhasilan pendidikan sains yang dilakukan oleh setiap negara. Namun kemampuan ini belum dilatihkan secara optimal melalui proses pembelajaran sains di Indonesia. Peneliti melakukan konstruksi soal yang bisa digunakan untuk mengukur kemampuan literasi saintifik siswa dalam domain kompetensi pada topik gerak lurus. Penelitian ini menggunakan penelitian deskriptif jenis survei dengan jumlah soal 18 butir. Populasi dalam penelitian ini adalah siswa kelas VIII di salah satu SMP Negeri di Kabupaten Bandung Barat dengan jumlah sampel sebanyak 140 orang siswa kelas VIII menggunakan pengambilan sampel acak. Dari hasil penelitian diperoleh koefisien reliabilitas (rhh) sebesar 0,73 (kategori tinggi) dengan validitas item, tingkat kesukaran, dan daya pembeda setiap butir soal yang beragam. Hasil yang diperoleh akan dijadikan acuan untuk menganalisis kesulitan literasi saintifik siswa SMP kelas VIII pada topik gerak lurus serta merekonstruksi rencana pembelajaran sains yang melatihkan literasi saintifik.
\end{abstract}

\begin{abstract}
Over the times, scientific literacy have been selected as the main purpose of science education.Scientific literacy is considered to be used to prepare the current generation for life in the future. Scientific literacy is an understanding of the concepts and processes of science and can use that understanding in everyday life. As the main purpose of science education, scientific literacy in everyday society be a description the success of science education undertaken by each country. However, this capability has not been trained optimally through the learning process of science in Indonesia. Researcher conducted a construction matter that can be used to measure the literacy skills of students in the scientific domain competence on the topic of straight motion. This research use descriptive research type of survey with amount question 18 items. The population in this research is a class VIII student in one of the Junior High School in West Bandung regency with a total sample of 140 eighth grade students using random sampling. The result showed reliability coefficient (rhh) by 0.73 (high category) with the validity of the item, level of difficulty, and distinguishing each item on diverse. The results earned will be used as a reference for analyzing the difficulties of scientific literacy class VIII junior high school students on the topic of straight motion and reconstruct the science lesson plan which trains scientific literacy.
\end{abstract}

Keywords: Construction; Scientific Literacy Profile; Domain Competence

\section{PENDAHULUAN}

Literasi saintifik adalah pemahaman konsep dan proses sains serta bisa menggunakan pemahaman tersebut dalam keseharian. Pengertian ini didukung oleh [1], [2], [3] [4] [5] . Dalam penilaian literasi saintifik berdasarkan kerangka kerja PISA 2015, terdapat empat domain yang saling terkait, yaitu:

a. Domain konteks, meliputi konteks personal, lokal/nasional dan global.

b. Domain kompetensi, meliputi aspek kemampuan untuk menjelaskan fenomena sains, merancang dan mengevaluasi 


\section{Adib Rifqi dkk, Rancangan Soal Domain Kompetensi Literasi Saintifik}

penyelidikan sains, serta menafsirkan data dan bukti sains.

c. Domain pengetahuan, meliputi aspek pengetahuan konten, pengetahuan prosedural, dan pengetahuan epistemik.

d. Domain sikap seseorang terhadap sains, ditandai dengan minat dalam sains dan teknologi, mengapresiasi pendekatan sains untuk penyelidikan, serta tanggapan dan kesadaran terhadap masalah lingkungan.

Seiring perkembangan zaman, literasi saintifik dipilih sebagai tujuan utama pendidikan sains. Literasi saintifik dianggap bisa digunakan untuk mempersiapkan generasi saat ini untuk menghadapi saat nanti, selaras dengan [6], [7], [8]. Sebagai tujuan utama dalam pendidikan sains, literasi saintifik dalam keseharian masyarakat menjadi gambaran keberhasilan pendidikan sains yang dilakukan oleh setiap negara. Di Indonesia sendiri, sudah diambil kebijakan untuk mendukung tujuan ini meski tidak dipaparkan secara gamblang [9] [10][11]

Bila dicermari, kemampuan ini belum dilatihkan secara optimal melalui proses pembelajaran sains di Indonesia. Sebagai contoh siswa belum dapat mengembangkan pertanyaan penyelidikan, eksperimen yang dibangun masih bersifat verifikasi terhadap buku teks (cookbook) [12]. Keadaan ini sesuai dengan hasil penilaian PISA terhadap siswa Indonesia terkait tingkat literasi saintifik yang menyebutkan bahwa sebagian besar siswa Republik Indonesia berada dalam level 1 literasi saintifik sedangkan sebagian kecil siswa Indonesia berada dalam level 2 literasi saintifik. Dua level ini terbilang rendah karena terdapat 6 level dalam penilaian PISA.

Oleh karena itu, peneliti memandang penting dilakukan penelitian untuk memberi gambaran permasalahan yang ada. Melalui gambaran ini dapat dilakukan beberapa langkah untuk mengatasinya. Salah satu caranya ialah dengan melakukan tes terhadap siswa dengan menggunakan soal yang selaras dengan PISA [13] .

Penelitian deskriptif ini bertujuan untuk mengetahui kualitas rancangan soal domain kompetensi literasi saintifik siswa sekolah menengah pertama (SMP) pada topik gerak lurus serta mengetahui perbaikan dari soal ini. Konstruksi disusun berdasarkan profil kesulitan literasi sains dan analisis Rencana Pelaksanaan Pembelajaran (RPP) yang digunakan. Rancangan soal menjadi acuan untuk menganalisis kesulitan literasi saintifik siswa SMP kelas VIII pada topik gerak lurus serta merekonstruksi Rencana Pelaksanaan Pembelajaran (RPP) yang melatihkan literasi saintifik.

\section{BAHAN DAN METODE}

Penelitian ini bertujuan untuk mengonstruksi rancangan soal domain kompetensi literasi saintifik siswa sekolah menengah pertama (SMP ) pada topik gerak lurus. Oleh karena itu, penelitian deskriptif ini menggunakan metode suvei dengan jenis cross-sectional survey. Dalam rancangan survei, peneliti mendeskripsikan secara kuantitatif kecenderungan-kecenderungan, perilakuperilaku, atau pendapat-pendapat dari populasi dengan meneliti sampel populasi tersebut [14]. Instrumen yang digunakan dalam penelitian ini terdiri dari:

a. Tes tipe uraian literasi saintifik (selanjutnya soal literasi saintifik) untuk mengukur literasi saintifik siswa dalam domain kompetensi; dan

b. Lembar validasi butir soal untuk memvalidasi kesesuaian indikator domain kompetensi literasi saintifik dengan soal kepada ahli.

Penelitian dilaksanakan di salah satu SMP Negeri di Kabupaten Bandung Barat. Populasi dalam penelitian sebanyak 140 orang adalah seluruh siswa kelas VIII tahun ajaran 20162017 di sekolah tersebut. Sampel diambil secara acak sesuai dengan [15] sebanyak 38 orang yang sudah memenuhi aturan pengambilan sampel mengacu pada [16]. Analisis yang dilakukan terhadap validitas item, tingkat kesukaran, daya pembeda, dan reliabilitas tes mengacu pada [17].

\section{HASIL DAN PEMBAHASAN}

Soal literasi saintifik yang digunakan berjumlah 18 butir pada topik gerak lurus dengan penyusunan mengacu pada kerangka kerja PISA 2015. Instrumen tes tipe uraian memiliki keunggulan untuk mengukur kemampuan individu dalam mengorganisasikan, mengintergasikan, menganalisis, menyintesiskan, dan mengevaluasi informasi [11].

Instrumen ini dianggap sesuai dengan indikator yang terdapat pada domain kompetensi dalam kerangka kerja PISA 2015 yang mengukur kemampuan siswa dalam 
menjelaskan fenomena ilmiah, merancang dan mengevaluasi penyelidikan ilmiah, serta menafsirkan data dan bukti ilmiah.

Rincian domain kompetensi yang diberikan melalui soal literasi saintifik masing-masing sebanyak 6 butir yang terbagi dalam 3 subtopik sesuai dengan sub-topik yang diajarkan ditampilkan melalui tabel 1.1. dan Tabel 1.2. berikut.

Tabel 1.1. Rincian Domain Kompetensi Soal Literasi Saintifik

\begin{tabular}{|c|c|c|}
\hline $\begin{array}{l}\text { No. } \\
\text { Soal }\end{array}$ & $\begin{array}{c}\text { Domain } \\
\text { Kompetensi }\end{array}$ & Indikator \\
\hline $\begin{array}{c}1 ; 7 \\
13\end{array}$ & \multirow{2}{*}{$\begin{array}{l}\text { Menjelaskan } \\
\text { fenomena } \\
\text { ilmiah }\end{array}$} & $\begin{array}{c}\text { Mengingat dan } \\
\text { menerapkan pengetahuan } \\
\text { ilmiah yang sesuai. }\end{array}$ \\
\hline $\begin{array}{c}2 ; 8 \\
14\end{array}$ & & $\begin{array}{c}\text { Mengidentifikasi, } \\
\text { menggunakan, dan } \\
\text { menghasilkan model yang } \\
\text { jelas dan representatif. }\end{array}$ \\
\hline $\begin{array}{c}3 ; 9 \\
15\end{array}$ & \multirow{2}{*}{$\begin{array}{l}\text { Merancang } \\
\text { dan } \\
\text { mengevaluasi } \\
\text { penyelidikan } \\
\text { ilmiah }\end{array}$} & $\begin{array}{c}\text { Mengusulkan cara } \\
\text { mengeksplorasi } \\
\text { pertanyaan yang diberikan } \\
\text { secara ilmiah. }\end{array}$ \\
\hline $\begin{array}{c}4 ; 10 \\
16\end{array}$ & & $\begin{array}{c}\text { Mengevaluasi cara } \\
\text { mengeksplorasi } \\
\text { pertanyaan yang diberikan } \\
\text { secara ilmiah. }\end{array}$ \\
\hline $\begin{array}{c}5 ; 11 ; \\
17\end{array}$ & \multirow{2}{*}{$\begin{array}{l}\text { Menafsirkan } \\
\text { data dan } \\
\text { bukti ilmiah }\end{array}$} & $\begin{array}{l}\text { Mengevaluasi argumen } \\
\text { ilmiah dan bukti dari } \\
\text { berbagai sumber. }\end{array}$ \\
\hline $\begin{array}{c}6 ; 12 \\
18\end{array}$ & & $\begin{array}{c}\text { Menganalisis dan } \\
\text { menafsirkan data serta } \\
\text { menarik kesimpulan yang } \\
\text { tepat. }\end{array}$ \\
\hline
\end{tabular}

Tabel 1.2. Rincian Sub Topik Gerak Lurus

\begin{tabular}{ccc}
\hline Soal & $\begin{array}{c}\text { No. } \\
\text { Soal }\end{array}$ & Sub Topik \\
\hline I & $1-6$ & $\begin{array}{c}\text { Gerak Lurus Berubah } \\
\text { Beraturan (GLBB) }\end{array}$ \\
\hline II & $7-12$ & Gerak Lurus Beraturan (GLB) \\
\hline III & $13-18$ & Gerak dan Variabelnya \\
\hline
\end{tabular}

Validasi soal dilakukan kepada tiga ahli yang masing-masing fokus pada tiga aspek berikut: kesesuaian indikator dengan soal, jawaban dengan pertanyaan, serta soal dengan jenjang sekolah.

Berdasarkan hasil validasi ahli terhadap 18 butir soal literasi saintifik diperoleh hasil 17 butir soal sudah sesuai tanpa perbaikan dengan indikator yang diukur dan 1 butir soal perlu perbaikan. Untuk kesesuaian pertanyaan dengan jawaban, 9 butir soal sudah sesuai tanpa perbaikan dan 10 soal sesuai dengan perbaikan. Sementara untuk kesesuaian soal dengan jenjang sekolah, terdapat 11 butir soal yang sudah sesuai tanpa perbaikan dan 7 butir soal sesuai dengan perbaikan. Rincian hasil validasi ahli dipaparkan melalui tabel 1.3.

Pada kategori pertama, butir soal no. 18 perlu diperbaiki dengan alasan bahwa soal yang pertama disusun kurang sesuai dengan indikator yang diukur. Indikator yang diukur adalah menganalisis dan menafsirkan data serta menarik kesimpulan yang tepat sedangkan soal yang disusun lebih tepat untuk mengukur indikator mengingat dan menerapkan pengetahuan ilmiah yang sesuai. Dengan demikian, perbaikan dilakukan dengan mengubah soal.

Pada kategori kedua, soal yang perlu diperbaiki secara garis besar terdapat pada jawaban yang tidak selaras dengan konsep. Misalnya kecepatan yang seharusnya berkaitan dengan perpindahan, ditulis berkaitan dengan jarak tempuh. Dengan demikian, perbaikan dilakukan dengan menyelaraskan konsep yang terdapat pada jawaban.

Pada kategori ketiga, seluruh soal yang perlu diperbaiki terdapat pada redaksi bahasa dalam pertanyaan. Redaksi bahasa yang digunakan dipandang kurang sesuai dengan jenjang sekolah. Dengan demikian, perbaikan dilakukan dengan menyunting redaksi bahasa yang digunakan dalam pertanyaan.

Oleh karena itu, berdasarkan hasil validasi ahli dapat disimpulkan bahwa soal sudah bisa digunakan.

Tabel 1.3. Hasil Validasi Ahli

\begin{tabular}{cccc} 
No. & $\begin{array}{c}\text { Kesesuaian } \\
\text { indikator } \\
\text { dengan } \\
\text { soal }\end{array}$ & $\begin{array}{c}\text { Kesesuaian } \\
\text { jawaban } \\
\text { dengan } \\
\text { pertanyaan }\end{array}$ & $\begin{array}{c}\text { Kesesuaian } \\
\text { soal } \\
\text { dengan } \\
\text { jenjang } \\
\text { sekolah }\end{array}$ \\
\hline 1 & S & SP & S \\
2 & S & S & SP \\
3 & S & S & SP \\
4 & S & SP & SP \\
5 & S & SP & SP \\
6 & S & SP & S \\
7 & S & SP & S \\
8 & S & SP & S \\
9 & S & S & SP \\
10 & S & S & S \\
11 & S & S & S \\
12 & S & S & S \\
13 & S & S & SP \\
14 & S & SP & S \\
15 & S & SP & SP \\
16 & S & S & S \\
17 & S & SP & S \\
18 & SP & SP & S \\
\hline Keterangan & & & \\
\hline
\end{tabular}

Keterangan:

$\mathrm{S}$ = sesuai 
$\mathrm{SP}=$ sesuai dengan perbaikan

$\mathrm{T}=$ tidak sesuai

Selanjutnya, peneliti melihat kelayakan soal yang dianalisis berdasarkan hasil uji coba soal. Hasil uji coba ini menjadi acuan peneliti dalam melihat nilai validitas item, reliabilitas tes, daya pembeda, dan tingkat kesukaran pada setiap butir soal. Melalui uji coba juga bisa didapatkan informasi banyak waktu yang diperlukan siswa untuk menjawab soal. Berdasarkan hasil uji coba soal, didapat analisis hasil uji coba yang dipaparkan melalui tabel 1.4.

Dari analisis hasil uji coba didapat hasil seluruh soal literasi saintifik valid dengan rincian kategori 2 butir soal tinggi, 6 butir soal cukup, 6 butir soal rendah, dan 4 butir soal sangat rendah. Tingkat kesukaran didapat beragam dengan rincian kategori 1 butir soal sukar, 7 butir soal sedang, 10 butir soal mudah. Daya pembeda didapat beragam dengan rincian kategori 3 butir soal baik, 7 butir soal cukup, dan 8 butir soal jelek. Sementara reliabilitas soal didapat pada kategori tinggi.

Berdasarkan hasil dan pembahasan yang telah dilakukan, dapat dikatakan bahwa soal sudah bisa digunakan untuk mengukur indikator domain kompetensi literasi saintifik pada topik gerak lurus di jenjang sekolah menengah pertama. Namun perlu dilakukan perbaikan karena uji coba yang dilakukan memberikan hasil validitas, tingkat kesukaran, dan daya pembeda pada kategori beragam serta reliabilitas pada kategori tinggi.

Perbaikan dari hasil yang diperoleh menjadi acuan untuk menganalisis kesulitan literasi saintifik siswa SMP kelas VIII pada topik gerak lurus serta merekonstruksi rencana pembelajaran sains yang melatihkan literasi saintifik yang telah disusun oleh [8].

\section{UCAPAN TERIMA KASIH}

Penulis mengucapkan terima kasih atas bimbingan dosen Pendidikan Fisika UPI Dr. Setiya Utari, M. Si. dan Muhamad Gina Nugraha, S.Pd., M.Pd., M.Si., selama penelitian berlangsung; Dr. Endi Suhendi, M.Si., Duden Saepuzaman, M.Si., dan Drs. Tarma Anda yang bersedia melakukan validasi soal; serta siswa kelas VIII G SMP Negeri 2 Lembang yang menyediakan waktunya untuk menjadi sampel penelitian.

Tabel 1.4. Analisis Hasil Uji Coba

\begin{tabular}{|c|c|c|c|c|c|c|c|}
\hline \multirow{2}{*}{ No. } & \multirow{2}{*}{ Soal } & \multicolumn{2}{|c|}{ Validitas Item } & \multicolumn{2}{|c|}{$\begin{array}{c}\text { Tingkat kesukaran } \\
\text { (TK) }\end{array}$} & \multicolumn{2}{|c|}{$\begin{array}{c}\text { Daya Pembeda } \\
\text { (DP) }\end{array}$} \\
\hline & & Koef & Kategori & $\begin{array}{c}\text { Indeks } \\
\text { TK }\end{array}$ & Kategori & $\begin{array}{l}\text { Indeks } \\
\text { DP }\end{array}$ & Kategori \\
\hline 1 & \multirow{6}{*}{1} & 0,18 & Sangat Rendah & 0,92 & Mudah & 0,05 & Jelek \\
\hline 2 & & 0,27 & Rendah & 0,95 & Mudah & 0,00 & Jelek \\
\hline 3 & & 0,05 & Sangat Rendah & 0,68 & Sedang & 0,11 & Jelek \\
\hline 4 & & 0,43 & Cukup & 0,29 & Sukar & 0,26 & Cukup \\
\hline 5 & & 0,42 & Cukup & 0,34 & Sedang & 0,26 & Cukup \\
\hline 6 & & 0,34 & Rendah & 0,66 & Sedang & 0,37 & Cukup \\
\hline 7 & \multirow{6}{*}{ II } & 0,22 & Rendah & 0,95 & Mudah & 0,00 & Jelek \\
\hline 8 & & 0,03 & Sangat Rendah & 0,95 & Mudah & 0,00 & Jelek \\
\hline 9 & & 0,67 & Tinggi & 0,55 & Sedang & 0,68 & Baik \\
\hline 10 & & 0,22 & Rendah & 0,47 & Sedang & 0,32 & Cukup \\
\hline 11 & & 0,51 & Cukup & 0,34 & Sedang & 0,37 & Cukup \\
\hline 12 & & 0,58 & Cukup & 0,68 & Sedang & 0,42 & Baik \\
\hline 13 & \multirow{6}{*}{ III } & 0,18 & Sangat Rendah & 0,95 & Mudah & 0,11 & Jelek \\
\hline 14 & & 0,42 & Cukup & 0,87 & Mudah & 0,16 & Jelek \\
\hline 15 & & 0,62 & Tinggi & 0,71 & Mudah & 0,47 & Baik \\
\hline 16 & & 0,43 & Cukup & 0,89 & Mudah & 0,21 & Cukup \\
\hline 17 & & 0,28 & Rendah & 0,74 & Mudah & 0,21 & Cukup \\
\hline 18 & & 0,30 & Rendah & 0,92 & Mudah & 0,05 & Jelek \\
\hline
\end{tabular}




\section{DAFTAR PUSTAKA}

[1] Hurd, P. DeH. (1958). Science literacy: Its meaning for American schools. Educational Leadership, 16, 13-16, 52.

[2] National Academy of Science. (1995). National Science Education Standards. Washington, D.C.: National Academy Press.

[3] OECD. (2013) PISA 2015 Draft Science Frame Work. Paris: OECD.

[4] Utari, S., Karim, S., Setiawan, A., Nugraha, M. G., Saepuzaman, D., \& Prima, E. C. (2015). Designing Science Learning for Training Students' Science Literacies at Junior High School Level. In Int. Conf. on Mathematics, Science, and Education (pp. 1-6).

[5] Samsudin, A., Suhendi, E., Efendi, R., \& Suhandi, A. (2012). Pengembangan "Cels" dalam Eksperimen Fisika Dasar untuk Mengembangkan Performance Skills dan Meningkatkan Motivasi Belajar Mahasiswa. Jurnal Pendidikan Fisika Indonesia, 8(1), 15-25.

[6] Holbrook, J. \& Rannikmae, M. (2009). The meaning of scientific literacy. International Journal of Environmental \& Science Education, 4(3), 275-288.

[7] Sudarisman, S. (2011). Tugas Rumah Berbasis Home Science Process Skill (HSPS) pada Pembelajaran Biologi untuk Mengembangkan Literasi Sains Siswa. Seminar Nasional VIII Pendidikan Biologi FPMIPA UNS.

[8] Hayat, B. (2011). Benchmark Internasional Mutu Pendidikan. Jakarta: Bumi Aksara.

[9] Kementerian Pendidikan dan Kebudayaan. (2013). Peraturan Menteri Pendidikan dan Kebudayaan Nomor 58 Tahun 2014 Tentang Kurikulum 2013 Sekolah Menengah Pertama/Madrasah Tsanawiyah. Jakarta: Kemendikbud.

[10] Kulsum, F., Rochman, C., \& Nasrudin, D. (2017). Profil Literasi Sains Peserta Didik Pada Konsep Pembangkit Listrik Tenaga Air (Plta) Cirata Di Kabupaten Cianjur Jawa Barat. Wahana Pendidikan Fisika, 2(1).

[11] Nehru, N., \& Syarkowi, A. (2017). Analisis Desain Pembelajaran Untuk Meningkatkan Literasi Sains Berdasarkan Profil Penalaran IImiah. Wahana Pendidikan Fisika, 2(1).
[12] Alam, D.P. (2015). Rekonstruksi Rancangan Rencana Pelaksanaan Pembelajaran Sains Melalui Analisis Kesulitan Literasi Sains Siswa SMP Kelas VII pada Topik Gerak Lurus. (Skripsi). Bandung: UPI.

[13] Creswell, J.W. (2014). Research Design Pendekatan Kualitatif, Kuantitatif, dan Mixed. Yogyakarta: Pustaka Pelajar.

[14] Sugiyono. (2011). Metode penelitian pendidikan. Bandung : Alfabeta.

[15] Fraenkel, J.R. \& Wallen N.E. (2009). How to design and evaluate research in education. New York : McGraw-Hill Companies.

[16] Sugiyono. (2015). Metode penelitian pendidikan (pendekatan kuantitatif, kualitatif, dan R\&D). Bandung : Alfabeta.

[17] Arikunto, S. (2013). Dasar-dasar evaluasi pendidikan. Jakarta : Bumi Aksara 